\title{
Holocene Environmental Variability in Southern Greenland Inferred from Lake Sediments
}

\author{
Michael R. Kaplan ${ }^{1}$ \\ Department of Geology and Geophysics, University of Wisconsin, 1215 W. Dayton St., Madison, Wisconsin, 53706 \\ E-mail: kaplanm@geology.wisc.edu. \\ Alexander P. Wolfe \\ Department of Earth and Atmospheric Sciences, University of Alberta, Edmonton, Alberta T6G 2E3, Canada
}

and

Gifford H. Miller

Institute of Arctic and Alpine Research and Department of Geological Sciences, University of Colorado, Colorado, 80309-0450

Received October 18, 2001

Sediments from Qipisarqo Lake provide a continuous Holocene paleoenvironmental record from southern Greenland. Following deglaciation and glacio-isostatic emergence of the basin from the sea $\sim 9100$ cal yr B.P., proxies of lake paleoproductivity, including biogenic silica and organic matter, increased markedly until $6000 \mathrm{cal}$ yr B.P. and thereafter remained stable over the ensuing warm three millennia. Subsequent decreases in these proxies, most dramatically between 3000 and 2000 cal yr B.P., show the lake's responses to initial Neoglacial cooling. Intervals of ameliorated limnological conditions occurred between 1300 and 900 and between 500 and 280 cal yr B.P., briefly interrupting the decreasing trend in productivity that culminated in the Little Ice Age. Increased lake productivity during the latter half of the 20th century, which reflects the limnological response to circum-arctic warming, still has not reached peak Holocene values. The Neoglacial climate of the last $2000 \mathrm{yr}$ includes the most rapid high-amplitude environmental changes of the past nine millennia. The Norse thus migrated around the North Atlantic Ocean region in the most environmentally unstable period since deglaciation. Lacustrine sediment records provide a context with which to consider future environmental changes in the Labrador Sea region. In particular, any future warming will be superposed on a regional climate system that is currently exhibiting highly unstable behavior at submillennial timescales. (๑) 2002 University of Washington.

\section{INTRODUCTION}

Information on past climatic and ecological variability provides a context in which to consider present and future environmental changes, thus improving our understanding of spatial

${ }^{1}$ To whom correspondence should be addressed. patterns and underlying mechanisms of natural climate variability. The Arctic is particularly important in this regard, given its susceptibility to anthropogenic warming due to the sensitivity of albedo to relatively small changes in snow and ice cover (Overpeck et al., 1997; Rouse et al., 1997; MacDonald et al., 2000). Although a number of paleoenvironmental studies have been conducted in northwestern (Blake et al., 1992), western (Kelly, 1985; Willemse and Törnqvist, 1999; Bennike, 2000), and eastern (Cremer et al., 2001) coastal Greenland, relatively little is known from the southern part of the island, despite its strategic location in relation to adjacent North Atlantic oceanographic currents and dynamics.

Lake sediments offer continuous and datable paleoenvironmental archives that may frequently be interpreted in climatic terms. This study reports paleolimnological inferences regarding Holocene climatic variability from a small lake in southern Greenland. Our reconstruction of the area's environmental history is based on the lake sediments' physical-chemical properties, including magnetic susceptibility, density, water content, and biogenic silica and organic matter concentration, which have been widely demonstrated to be a function of changes in watershed and lake characteristics (e.g., Noon et al., 2001). In turn, watershed and lake physical-chemical properties have been strongly linked to climatic and glacial influences in high-latitude regions, especially where ice cover exists for much of the year (e.g., Rouse et al., 1997; MacDonald et al., 2000; Joynt and Wolfe, 2001; Noon et al., 2001).

Our findings illustrate significant paleoenvironmental variability throughout the Holocene, but especially during the last $3000 \mathrm{yr}$, which is in contrast to the warmer and more stable conditions of the middle Holocene. The most rapid shifts occur stratigraphically back-to-back in the most recent sediment 
record, including the Little Ice Age (LIA), which marks the single largest Holocene glacial advance, and subsequent warming that probably includes, in the second half of the 20th century, some degree of amplification from anthropogenic greenhouse gas emissions.

\section{STUDY SITE}

Qipisarqo Lake $\left(61^{\circ} 00^{\prime} 41^{\prime \prime} \mathrm{N}, 47^{\circ} 45^{\prime} 13^{\prime \prime} \mathrm{W}\right)$ is situated on a coastal lowland (7 $\mathrm{m}$ above sea level [asl]) less than $1 \mathrm{~km}$ from the shores of the inner reach of Kobberminebugt, a large fiord system that connects directly to the open ocean $30 \mathrm{~km}$ to the west. The terminus of a large outlet of the Greenland Ice Sheet, Nordre Qipisarqo Bræ, is less than $2 \mathrm{~km}$ from the lake (Fig. 1). However, the lake is not presently influenced by glacial meltwater due to a morainic hill that diverts proglacial drainage to the west and south of the lake's catchment. Thus, any advance greater than $1 \mathrm{~km}$ beyond the present terminus would impinge into the catchment of Qipisarqo Lake, supplying glacial sediment to an otherwise nonglacial closed basin system. Limnologically, the lake's waters are highly dilute and ultra-oligotrophic, although proximity to the ocean is clearly reflected by dominance of the sea-salt ions $\mathrm{Cl}^{-}, \mathrm{SO}_{4}^{2-}, \mathrm{Na}^{+}$and $\mathrm{Ca}^{2+}$ (Table 1).

The climate of southern Greenland is influenced by both cold air masses associated with proximity to the ice sheet, and warmer maritime air related to the regional oceanographic circulation pattern (Funder, 1989). The southwestern coast receives the highest precipitation of all of Greenland due to the presence of the warm West Greenland Current (Fig. 1) which integrates waters of the cold East Greenland Current and warm Atlantic waters derived from the Irminger Current (Putnins, 1970). At Ivigtut, $30 \mathrm{~km}$ northwest of Qipisarqo Lake, mean annual temperature is $1.8^{\circ} \mathrm{C}$ with an annual range of $15.3^{\circ} \mathrm{C}$, whereas annual precipitation is $130 \mathrm{~cm}$. Vegetation is moderately lush shrub tundra dominated by shrub birch (Betula) and heaths (Cassiope, Empetrum, Vaccinium). Although shrub alder (Alnus) is regionally common at the heads of fiords, it is not present on the

TABLE 1

\begin{tabular}{|c|c|}
\hline Parameter & Value \\
\hline $\mathrm{pH}$ & 6.62 \\
\hline Conductivity & $27 \mu \mathrm{S} \cdot \mathrm{cm}^{-1}$ \\
\hline $\mathrm{Cl}^{-}$ & $3.23 \mathrm{mg} \cdot \mathrm{L}^{-1}$ \\
\hline $\mathrm{Na}^{+}$ & $1.79 \mathrm{mg} \cdot \mathrm{L}^{-1}$ \\
\hline $\mathrm{SO}_{4}^{2-}$ & $1.24 \mathrm{mg} \cdot \mathrm{L}^{-1}$ \\
\hline $\mathrm{Ca}^{2+}$ & $1.10 \mathrm{mg} \cdot \mathrm{L}^{-1}$ \\
\hline $\mathrm{Mg}^{2+}$ & $0.48 \mathrm{mg} \cdot \mathrm{L}^{-1}$ \\
\hline $\mathrm{SiO}_{2}$ & $0.40 \mathrm{mg} \cdot \mathrm{L}^{-1}$ \\
\hline $\mathrm{K}^{+}$ & $0.28 \mathrm{mg} \cdot \mathrm{L}^{-1}$ \\
\hline $\mathrm{PO}_{4}^{3-}$ & $<0.002$ (d.1.) $\mathrm{mg} \cdot \mathrm{L}^{-1}$ \\
\hline $\mathrm{NH}_{4}^{+}$ & $<0.001$ (d.1.) $\mathrm{mg} \cdot \mathrm{L}^{-1}$ \\
\hline $\mathrm{NO}_{3}^{-}$ & $<0.001$ (d.1.) $\mathrm{mg} \cdot \mathrm{L}^{-1}$ \\
\hline
\end{tabular}

d.1.: detection limit.

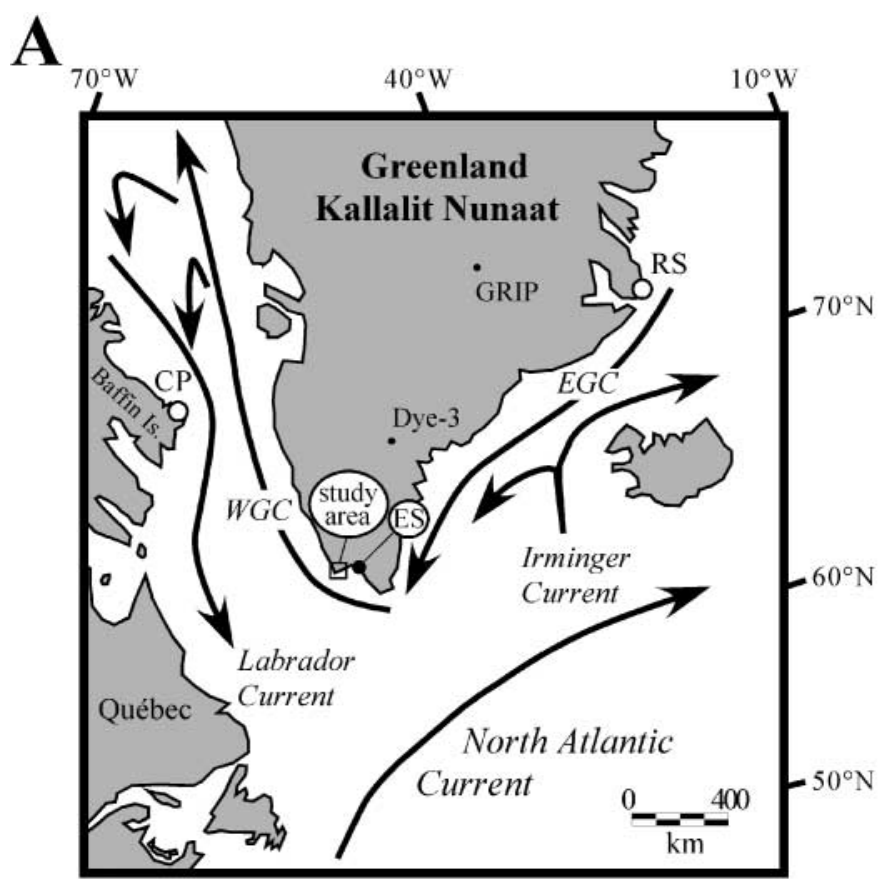

B



FIG. 1. A: Location of the study area in relationship to major North Atlantic Ocean currents including WGC (West Greenland Current) and EGC (East Greenland Current). The locations of other sites mentioned in the text are abbreviated as follows: CP (Cumberland Peninsula, Baffin Island), RS (Raffles S $\emptyset$, Jameson Land), and ES (Norse eastern settlement). B: Local situation of Qipisarqo Lake between inner Kobberminebugt and Nordre Qisarqo Bræ. The 100-m contour delimits the hill that presently impedes proglacial drainage from entering the lake.

Qipisarqo foreland, presumably due to the glacier's proximity. Local bedrock includes several Proterozoic crystalline lithologies, mainly gneisses and migmatites with various plutonic bodies. Although the exact position of the Greenland Ice Sheet during the Late Wisconsinan is unknown, it most likely extended well onto the continental shelf (Funder, 1989). Retreat to the outer coast was probably complete by about $11,500{ }^{14} \mathrm{C}$ yr B.P. (Bennike, 2000). 


\section{METHODS}

The complete sediment sequence from Qipisarqo Lake was obtained by overlapping a percussion core (Nesje, 1992) for the lower $267 \mathrm{~cm}$ with a $17-\mathrm{cm}$ gravity core that preserved the mud-water interface intact (Glew, 1989). Both cores were retrieved through the ice in May 1998 from the lake's western basin, in a water depth of $9 \mathrm{~m}$. The gravity core was extruded in continuous $0.25-\mathrm{cm}$ increments in the field, whereas the percussion core was split lengthwise, described, and sampled in the laboratory. Volumetric subsamples $\left(0.65 \mathrm{~cm}^{3}\right)$ were taken in the percussion core every $2 \mathrm{~cm}$, except around lithologic boundaries where sampling was every $1 \mathrm{~cm}$. In the gravity core, sampling intervals increase from 0.25 to $0.5 \mathrm{~cm}$ between core top and $3.75 \mathrm{~cm}$ depth, and from 1 to $2 \mathrm{~cm}$ between 3.75 and $10.25 \mathrm{~cm}$ depth. All samples were dried at $35^{\circ} \mathrm{C}$ overnight (i.e., for at least $16 \mathrm{~h}$ ) and weighed to obtain sediment water content and density. Consistency between neighboring samples and repeated measurements on samples throughout the core, specifically where water content is highest, showed reproducibility indicating sediment water was removed. Magnetic susceptibility (MS) was measured with a Bartington system on both wet and dry samples (there was no significant difference). Dried sediments were

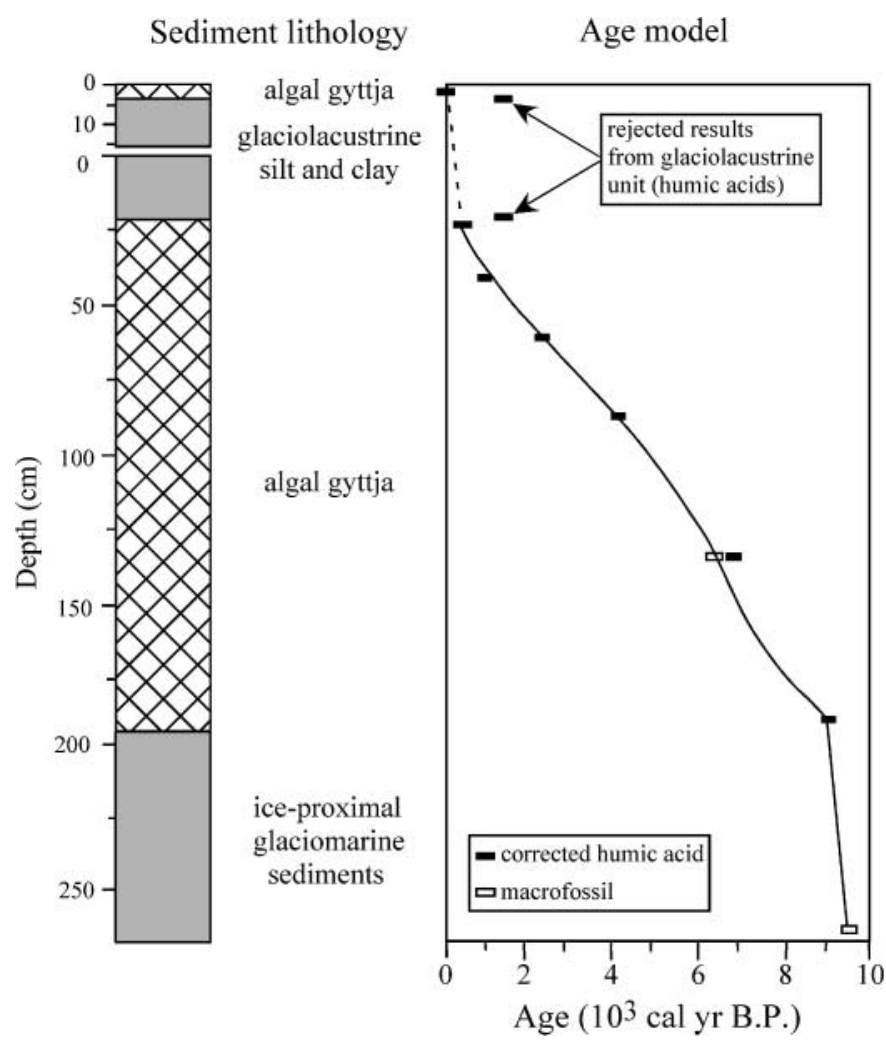

FIG. 2. Sediment lithostratigraphy and ${ }^{14} \mathrm{C}$ ages. The age model for the percussion core is shown on the right (polynomial fit to $194 \mathrm{~cm}$, linear 194-267 cm). We infer the two ${ }^{14} \mathrm{C}$ ages from the glaciolacustrine unit associated with sedimentation during the LIA reflect reworking of old carbon during glacial advance. heated overnight in ceramic crucibles at $105^{\circ} \mathrm{C}$, weighed to obtain \% hygroscopic moisture (by mass), and subsequently ignited at $550-600^{\circ} \mathrm{C}$ to derive mass loss on ignition (LOI), a measure of sediment organic matter content (e.g., Dean, 1974; Heiri et al., 2001).

In the percussion core, a less densely spaced set of samples, taken every $2 \mathrm{~cm}$ in the upper $60 \mathrm{~cm}$ of the sequence and $6-$ $12 \mathrm{~cm}$ below $60 \mathrm{~cm}$, was prepared for grain size and biogenic silica analyses. In the gravity core, sampling intervals increase from 0.25 to $1 \mathrm{~cm}$ between the core top to $3.75 \mathrm{~cm}$ depth, and 0.75 to $2 \mathrm{~cm}$ between 3.75 and $10.5 \mathrm{~cm}$ depth $(7.5 \mathrm{~cm}$ depth for biogenic silica). Grain size analyses were performed on a Malvern laser diffraction particle size analyzer and are restricted to the lacustrine sediment units. For biogenic silica $\left(\mathrm{BSiO}_{2}\right)$ a sequential dissolution methodology was used (Mortlock and Froelich, 1989; Carter and Coleman, 1994). On freeze-dried sediment, organic matter and carbonates were first removed with $10 \% \mathrm{H}_{2} \mathrm{O}_{2}$ and $1 \mathrm{~N} \mathrm{HCl}$ for $1 \mathrm{~h}$ in a $70-80^{\circ} \mathrm{C}$ water bath. Then, $\mathrm{BSiO}_{2}$ was dissolved by treating samples with $2 \mathrm{~N} \mathrm{NaCO}_{3}$ for $5 \mathrm{~h}$, also at $70-80^{\circ} \mathrm{C}$, with complete sample agitation every hour. Samples were thereafter centrifuged, and $1.0 \mathrm{ml}$ aliquots of supernatant were removed, to which $0.25 \mathrm{ml} 70 \% \mathrm{HNO}_{3}$ and $8.5 \mathrm{ml}$ of deionized $\mathrm{H}_{2} \mathrm{O}$ were added. Total $\mathrm{Si}$ and $\mathrm{Al}$ were measured on these aliquots by inductively coupled plasma-atomic emission spectroscopy (ICP-AES). Reproducibility for duplicate analyses is less than $\pm 4 \%$. To test whether sediment $\mathrm{BSiO}_{2}$ dissolution was complete after $5 \mathrm{~h}$, aliquots of supernatant were taken from a range of samples at $1-\mathrm{h}$ intervals up to $7 \mathrm{~h}$, and analyzed for $\mathrm{Si}$ and $\mathrm{Al}$. After $5 \mathrm{~h}$ of extraction time, concentrations of $\mathrm{Si}$ and $\mathrm{Al}$ had stabilized in all samples, and microscopic inspection of the samples revealed no remaining siliceous microfossils. After correcting raw ICP-AES measurements against procedural blanks, total Al was used to correct Si concentrations for contributions from clay mineral dissolution. Total Al was multiplied by 2 (the average molar ratio of $\mathrm{Si}: \mathrm{Al}$ in most clays; Eggimann et al., 1980) and then subtracted from the total measured Si. We emphasize that correction for the aluminosilicate contribution only slightly alters the value and never changes the sign of a result or conclusions. The first derivative of the raw $\mathrm{BSiO}_{2}$ data set was computed by the central difference approximation technique (Smith, 1985), which estimates the slope between every successive pair of $\mathrm{BSiO}_{2}$ measurements. Although this translates to the between-sample rate of change in $\% \mathrm{BSiO}_{2}$ (positive or negative), the calculation itself is independent of the age model assigned to the sediments.

Sediment chronology is based on a series of accelerator mass spectrometry (AMS) ${ }^{14} \mathrm{C}$ measurements, which target the depths of major lithologic boundaries and changes in sediment proxies. Despite an extensive search, macrofossils were only recovered from two depths (136 and $264 \mathrm{~cm}$ ). All additional dates were performed on sediment humic acid extracts (Abbott and Stafford, 1996). Samples were prepared at the Laboratory for AMS Radiocarbon Preparation and Research (University of Colorado) and measured at either the National Ocean Sciences AMS Facility (Woods Hole Oceanographic Institution) or 
Center for Accelerator Mass Spectrometry, Lawrence Livermore National Laboratory.

\section{RESULTS}

\section{Sediment Stratigraphy and Chronology}

The lower $73 \mathrm{~cm}$ of the percussion core comprise massive fine-grained glaciomarine muds that reflect sedimentation into an isostatically depressed lagoonal embayment. The transition to overlying organic lacustrine sediments (gyttja) is very abrupt, implying rapid uplift at the time of isolation from the sea, which is confirmed by the ${ }^{14} \mathrm{C}$ dating results (Fig. 2). The percussion core contains $171 \mathrm{~cm}$ of structureless olive-brown gyttja, which is capped by $23 \mathrm{~cm}$ of faintly laminated minerogenic, organicpoor sediment. Although the percussion core failed to recover any overlying organic sediments, the gravity core faithfully preserves the return to organic sedimentation in its upper $3.75 \mathrm{~cm}$ (Fig. 2). The gravity core gyttja is compositionally very similar to that in the percussion core.

The AMS ${ }^{14} \mathrm{C}$ dating results are reported on Table 2. Paired analyses of humic acid and macrofossils from $136 \mathrm{~cm}$ indicate

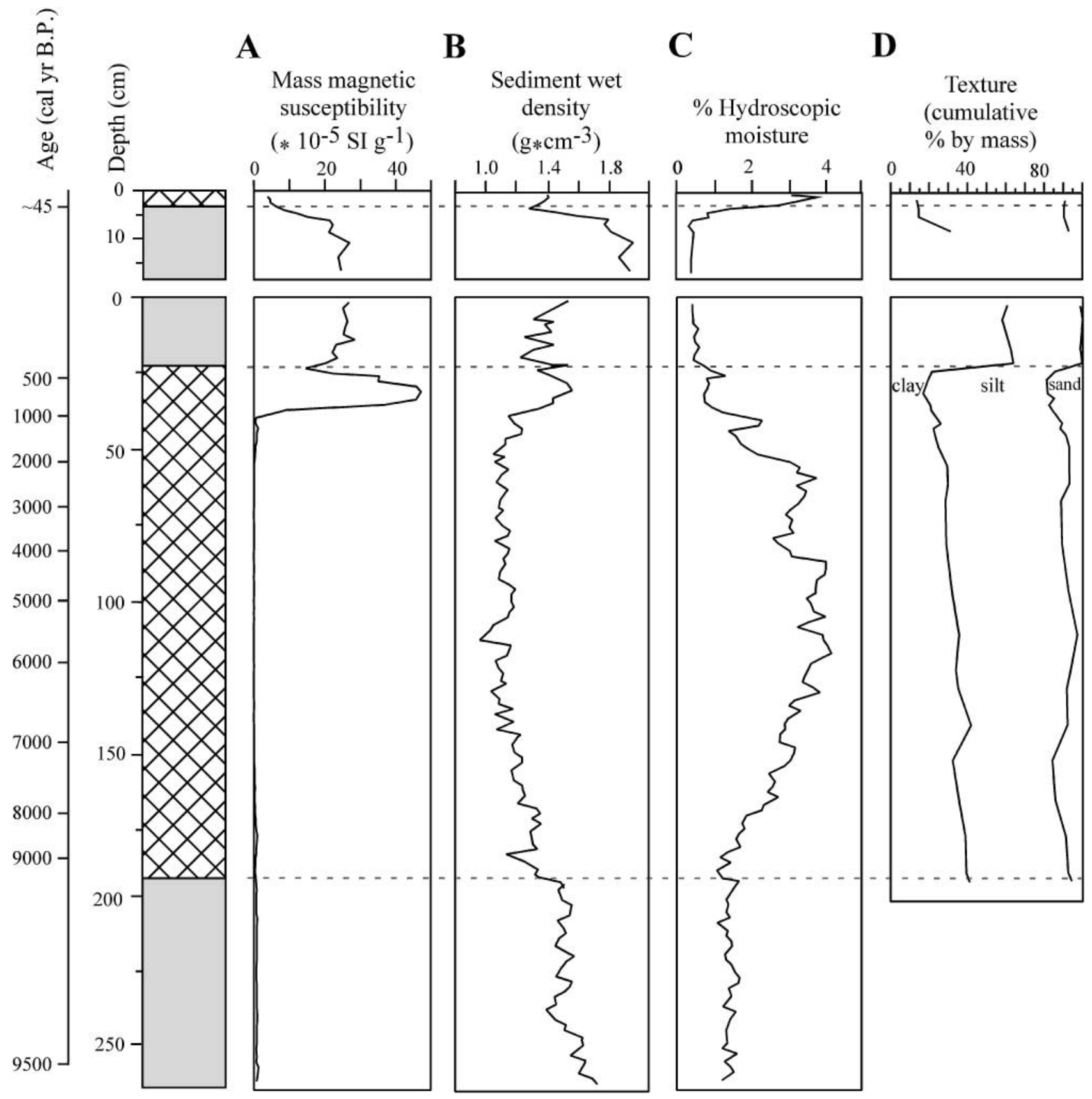

FIG. 3. Physical properties of the composite sediment stratigraphy from Qipisarqo Lake. 


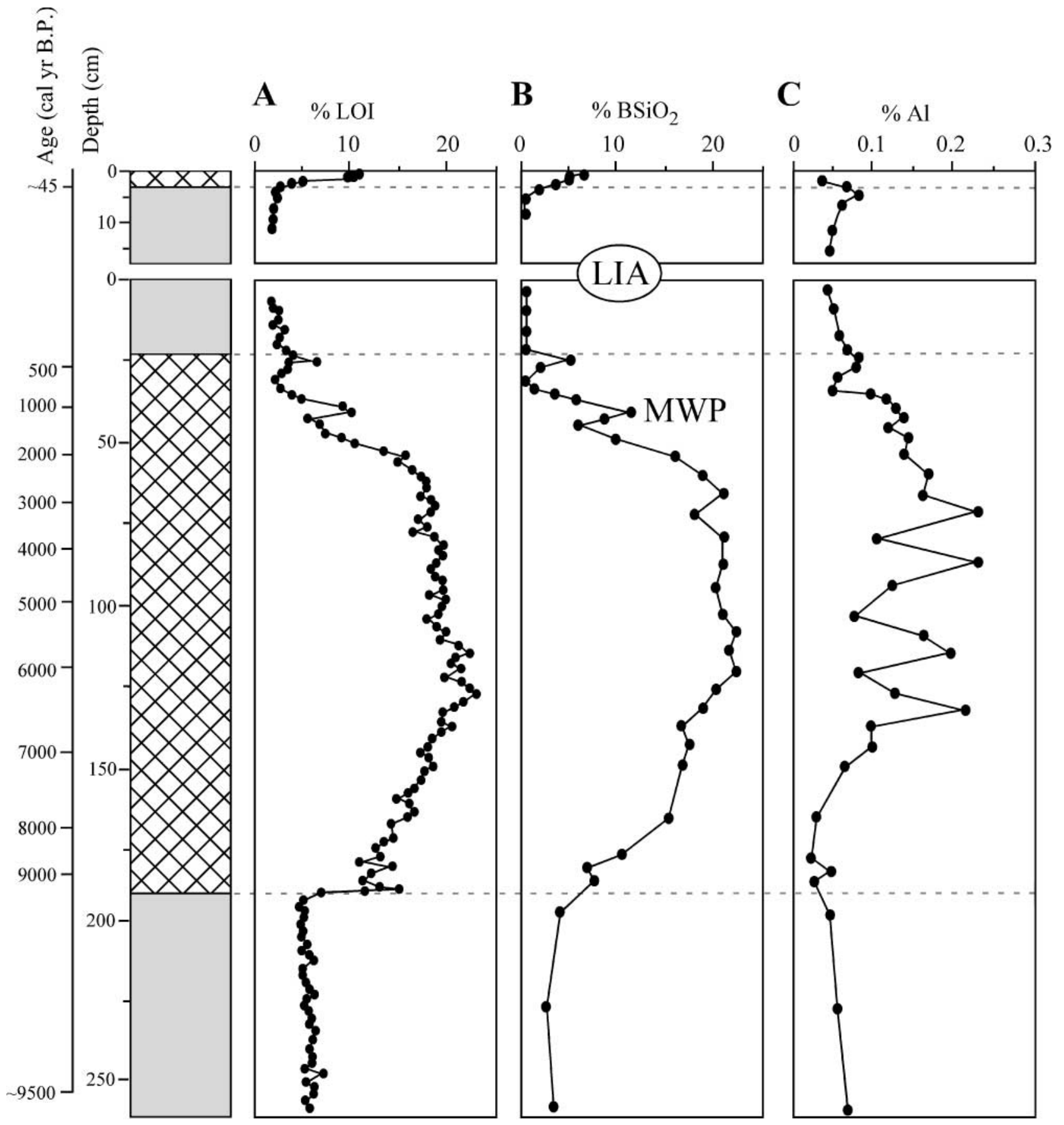

FIG. 4. Profiles of loss on ignition (LOI), $\mathrm{BSiO}_{2}$, and $\mathrm{Al}$ from the composite sediment stratigraphy from Qipisarqo Lake. LIA = Little Ice Age; $\mathrm{MWP}=\mathrm{Medieval}$ Warm Period.

that the former is $230 \mathrm{yr}$ older than the latter, an offset that reflects the lagged sequestration of the terrestrial component of humic acid to the lake's sediments (Abbot and Stafford, 1996). On Baffin Island, this offset is typically in the order of $300 \mathrm{yr}$ (Miller et al., 1999). In contrast, macrofossils from limnologically similar environments to Qipisarqo Lake, including aquatic bryophytes, have been documented as equilibrated with respect to atmospheric $\mathrm{CO}_{2}$ (Abbott and Stafford, 1996). Thus, the re- maining unpaired humic acid ages were corrected by subtracting the 230-yr offset measured at $136 \mathrm{~cm}$, and then calibrated to "calendar" years following Stuiver et al. (1998). All ages reported subsequently are in calibrated years (i.e., cal yr B.P.). The resulting model of sediment accumulation is almost linear for the organic portion of the percussion core (Fig. 2), resulting in an average sediment accumulation rate of $21 \mathrm{~cm} 10^{3} \mathrm{yr}^{-1}$. Dating of the minerogenic organic-poor unit proved problematic, however, 
TABLE 2

Radiocarbon Dating Results from the Qipisarqo Lake Cores

\begin{tabular}{|c|c|c|c|c|c|c|}
\hline $\begin{array}{l}\text { Depth } \\
(\mathrm{cm})\end{array}$ & $\begin{array}{l}\text { Radiocarbon age } \\
\left({ }^{14} \mathrm{C} \text { yr B.P. }\right)\end{array}$ & $\begin{array}{c}\delta^{13} \mathrm{C} \\
\% o\end{array}$ & $\mathrm{Lab}$ number ${ }^{a}$ & $\begin{array}{c}\text { Radiocarbon age } \\
\text { corrected } \\
\left({ }^{14} \mathrm{C} \text { yr B.P. }\right)^{b}\end{array}$ & $\begin{array}{c}\text { Calibrated Age } \\
\text { (solution range) } \\
(\text { cal yr B.P. } \pm 1 \sigma)^{c}\end{array}$ & Material Dated \\
\hline \multicolumn{7}{|c|}{ Glew core } \\
\hline 2 & $>$ Modern $^{d}$ & -25.1 & CURL-5578 & $>$ Modern & $>$ Modern & Humic acid extract \\
\hline 3.75 & $1300 \pm 35$ & $-25.0^{e}$ & CURL-4477 & $1070 \pm 35$ & $966(934-1047)$ & Humic acid extract \\
\hline \multicolumn{7}{|c|}{ Piston core } \\
\hline 20.0 & $1240 \pm 35$ & -25.1 & CURL-4475 & $1010 \pm 35$ & $930(923-952)$ & Humic acid extract \\
\hline 23.0 & $530 \pm 40$ & -22.9 & CURL-3036 & $300 \pm 40$ & $313(230-329)$ & Humic acid extract \\
\hline 40.0 & $1330 \pm 40$ & -23.2 & CURL-4486 & $1100 \pm 40$ & $1040(957-1056)$ & Humic acid extract \\
\hline 60.0 & $2570 \pm 35$ & -22.2 & CURL-4476 & $2340 \pm 35$ & 2347 (2339-2353) & Humic acid extract \\
\hline 86.5 & $3970 \pm 40$ & -20.9 & CURL-3037 & $3740 \pm 40$ & $4090(3991-4149)$ & Humic acid extract \\
\hline 136.0 & $5840 \pm 60$ & -20.5 & CURL-4487 & $5610 \pm 60$ & $6364(6308-6446)$ & Humic acid extract \\
\hline 136.0 & $5610 \pm 60$ & $-25.0^{e}$ & CURL-4488 & $5610 \pm 60$ & $6365(6308-6446)$ & Bryophyte and vascular leaf \\
\hline 187.5 & $8400 \pm 40$ & -18.1 & CURL-3038 & $8170 \pm 40$ & 9088 (9027-9249) & Humic acid extract \\
\hline 264.0 & $8560 \pm 50$ & $-25.0^{e}$ & CURL-4914 & $8560 \pm 50$ & 9533 (9502-9547) & Bryophyte \\
\hline
\end{tabular}

with two humic acid results (CURL-4475 and 4477) almost $1000 \mathrm{yr}$ older than expected, one each from the percussion core and gravity core (Table 2). The latter age is on the $\sim 3.75 \mathrm{~cm}$ transition to overlying gyttja. The simplest explanation of these inverted ages is that the minerogenic organic-poor unit contains a pool of old dissolved organic carbon. We infer that the upper unit in the percussion core (corresponding to the lower unit in the gravity core) is glaciolacustrine in origin based on the physical properties described below, specifically high silt clay percent and lack of fossil material, deposited due to the nearby proximity of the outlet glacier. The glacial advance would have reworked surrounding soils, causing old dissolved organic carbon to enter the sediment-laden meltwaters and thereafter transfer to the lake. The effects of such contamination would have been maximized by the low rates of autochthonous organic matter production at this time (see below).

Based on the ${ }^{14} \mathrm{C}$ evidence for the presence of reworked dissolved organic carbon (i.e., possible change in erosional regime in the catchment), including at the $3.75-\mathrm{cm}$ lithologic transition in the gravity core (Fig. 2), ${ }^{210} \mathrm{~Pb}$ dating of the gravity-core gyttja and underlying glaciolacustrine unit was not pursued. In the absence of reliable ${ }^{14} \mathrm{C}$ ages for the glaciolacustrine unit, an alternate approach was taken to assess the age of the transition to overlying organic sediments. First, from the 45-195 cm interval of the percussion core, which is lithologically almost identical to the recently deposited gyttja, mean dry density $\left(0.340 \mathrm{~g} \mathrm{~cm}^{-3}\right)$ and sediment accumulation rate $\left(0.0214 \mathrm{~cm} \mathrm{yr}^{-1}\right)$ were used to derive a term for dry mass flux $\left(6.86 \mathrm{mg} \mathrm{cm}^{-2} \mathrm{yr}^{-1}\right)$. The cumulative dry mass of the $3.75 \mathrm{~cm}$ of gyttja having accumulated above the glaciolacustrine unit was calculated as the summed product of depth and dry density for measurements over this interval $(n=8)$, resulting in a value of $0.308 \mathrm{~g} \mathrm{~cm}^{-2}$, which was then divided by the average Holocene dry mass flux $\left(6.86 \mathrm{mg} \mathrm{cm}^{-2}\right.$ $\left.\mathrm{yr}^{-1}\right)$, resulting in an age of $45 \mathrm{yr}$ for this lithological transition (Fig. 2). However approximate the age of $45 \mathrm{yr}$ may be for this hydrological change, given the similar properties between the gyttja in the gravity and percussion cores (Figs. 3 and 4) and the "modern" ${ }^{14} \mathrm{C}$ age at $2 \mathrm{~cm}$ (Table 2), this exercise strongly suggests that the lithological transition occurred recently in the 20 th century.

\section{Sediment Physical Properties}

For the most part, the sediment physical properties (Fig. 3) closely reflect sediment lithology. The glaciomarine unit carries a low MS signal and is of intermediate density $\left(1.4-1.8 \mathrm{~g} \mathrm{~cm}^{-3}\right)$ and hygroscopic moisture content (1-2\%). The onset of deposition of the lacustrine gyttja is marked by a decrease in sediment density and a progressive increase of hygroscopic moisture. Toward the top of the gyttja, the sediment physical properties begin to change, well before the abrupt transition to minerogenic glaciolacustrine sediment. For example, moisture content begins to decrease around $60 \mathrm{~cm}$, followed by rapid increases of MS and sediment density, both of which likely reflect an enhanced proportion of sand (Fig. 3D). After deposition of the minerogenic unit began, large proportions of clay were delivered, resulting in increased sediment density and partial dilution of the MS signal (Fig. 3). We infer that this clay-rich sediment was deposited due to advance of Nordre Qipisarqo Bræ into the lake's catchment based on physical differences from modern 
(i.e., gravity-core top) sediments (Figs. 2, 3). The physical characteristics of sediments deposited after retreat of the glacier from the catchment closely resemble those of percussion-core gyttja (Fig. 3).

\section{Biologically Mediated Sediment Properties}

LOI and $\mathrm{BSiO}_{2}$ are very tightly coupled $\left(r^{2}=0.93\right)$ throughout the Qipisarqo Lake sequence. After a marked, gradual increase from $\sim 180$ to $125 \mathrm{~cm}$, both proxies maintain high values ( $\sim 20 \%$ ) between 125 and $60 \mathrm{~cm}$ in the percussion core, which subsequently drop dramatically in the uppermost $30 \mathrm{~cm}$ of gyttja that immediately underlie the glaciolacustrine sediment (Fig. 4). This trend is punctuated by two minor recoveries prior to the lithological change at $\sim 24 \mathrm{~cm}$. Minimum values of LOI and $\mathrm{BSiO}_{2}$ are attained in the glaciolacustrine unit, although it is noteworthy that $\mathrm{BSiO}_{2}$ begins to recover before the return to organic sedimentation. Finally, there is striking, overall similarity between trends of $\mathrm{Al}$ and $\mathrm{BSiO}_{2}$ (and LOI). Aluminum in lake sediments has both allogenic and authigenic sources (Engstrom and Wright, 1984), both of which are likely represented by the total $\mathrm{Al}$ concentrations from Qipisarqo Lake. Although there is much variability in parts of the $\mathrm{Al}$ profile, based on the pronounced decrease in the $60-25 \mathrm{~cm}$ interval which changes in concert with decreasing $\mathrm{BSiO}_{2}$, despite enhanced (sand and silt) minerogenic input (Fig. 3), we infer that the $\mathrm{Al}$ stratigraphy is primarily influenced by weathering on the landscape and, perhaps more important, autochthonous source pools such as chelation by aquatic humic substances.

\section{DISCUSSION}

\section{Lake Production and Paleoclimate}

Given that $\mathrm{BSiO}_{2}$ is a direct measure of the paleoproduction of siliceous algae, it is by definition a proxy of purely aquatic origin (Conley, 1988). Biogenic silica in Qipisarqo Lake sediments is primarily composed of diatom valves, with occasional chrysophyte cysts, but no chrysophyte scales. Close correspondence between $\mathrm{BSiO}_{2}$ and LOI thus imply that much of the Qipisarqo Lake sediment organic matter is also of aquatic origin, although the ${ }^{14} \mathrm{C}$ dating results suggest that fluxes of (aged) terrestrial dissolved organic carbon must also be considered. Given that LOI values may also be a function of allochtonous organic material and the rate of in-lake decomposition of organic matter, we strongly rely on $\mathrm{BSiO}_{2}$ measurements when inferring changes in paleoproduction and assume LOI faithfully tracks biogenic silica. In all likelihood, diatom and chrysophyte paleoproduction covaries with that of the soft-bodied algae in this oligotrophic lake, resulting in increased autochthonous organic matter sedimentation in response to elevated total algal production. Thus, the diatoms themselves are likely also important vectors for sediment organic matter accumulation and dominantly influence LOI values in Figure 4. This is especially true given that the dominant diatoms in Qipisarqo Lake are relatively large and voluminous taxa (e.g., Pinnularia biceps, Aulacoseira spp., Tabellaria flocculosa; unpublished data), implying a high ratio of protoplasm mass to silica on a per cell basis.

In several previous studies, both $\mathrm{BSiO}_{2}$ (Colman et al., 1995; Edlund and Stoermer, 2000) and LOI (Levesque et al., 1993; Willemse and Törnqvist, 1999) have been interpreted as direct proxies of paleoclimatic variability. Such inferences assume a strong linkage between lake production and air temperature, which is supported by long-term monitoring studies (Schindler et al., 1990). The results from Qipisarqo Lake are entirely compatible with these notions, given the striking similarity between the lake's $\mathrm{BSiO}_{2}$ record and the borehole paleothermometry reconstruction from Dye3 (Dahl-Jensen et al., 1998), $500 \mathrm{~km}$ to the north (Figs. 1 and 5B, 5D). Unless a common paleoclimatic history is invoked, there is no a priori basis for any linkage between Qipisarqo Lake sediment proxies and the ice sheet's thermal history. Hence, the amplitude-locked correspondence between these records lends reassurance that climate history is indeed recorded by the lake sediment record.

\section{Holocene Climatic Evolution of Southern Greenland}

Following glacio-isostatic isolation of the basin from the sea ca. 9100 cal yr B.P., Qipisarqo Lake records progressive warming over the next three millennia. This warming is lagged relative to summer insolation high by about $4000 \mathrm{yr}$ (Fig. 5). In all likelihood, proximity to the Greenland Ice Sheet, and perhaps even the Laurentide, restrained early Holocene warming locally, through both direct atmospheric cooling as well as indirect effects involving meltwater and iceberg discharge into the neighboring ocean (Manabe and Broccoli, 1985). Despite the direct proximity of Qipisarqo Lake to the ice margin, there is no pronounced lithostratigraphic evidence for an early Holocene glacial advance corresponding to the regional North Atlantic cooling episode centered on 8200 cal yr B.P. (Alley et al., 1997; Barber et al., 1999). Although the $\mathrm{BSiO}_{2}$ sampling density in this section of the core may be insufficient to document short-lived events, LOI and other physical proxies suggest that southern Greenland remained relatively cool until ca. 8000 cal yr B.P. (Figs. 3 and 4). The interval from 6000 to $3000 \mathrm{cal} \mathrm{yr} \mathrm{B.P.}$ was marked by warmth and stability, and as such encompasses the Holocene thermal maximum expressed in southern Greenland. This interval integrates the influences of moderately high summer insolation and a warmer surrounding ocean, for which significantly reduced sea ice minimized the importance of highalbedo feedbacks (Kerwin et al., 1999).

Marked cooling is recorded shortly after $3000 \mathrm{cal}$ yr B.P. in the sediments of Qipisarqo Lake, corresponding closely with Neoglacial glacier advances regionally (Kelly, 1985; Fig. 5E) and likely in part a response to decreased solar insolation (Fig. 5A). The 3000-2000 cal yr B.P. interval is potentially a crucial interval of Neoglacial cooling, because it is so clearly manifested at a broad geographical scale around the Labrador Sea and Greenland (Fig. 5). On eastern Baffin Island, for example, molluscs with Arctic ecological affinities migrated southward 


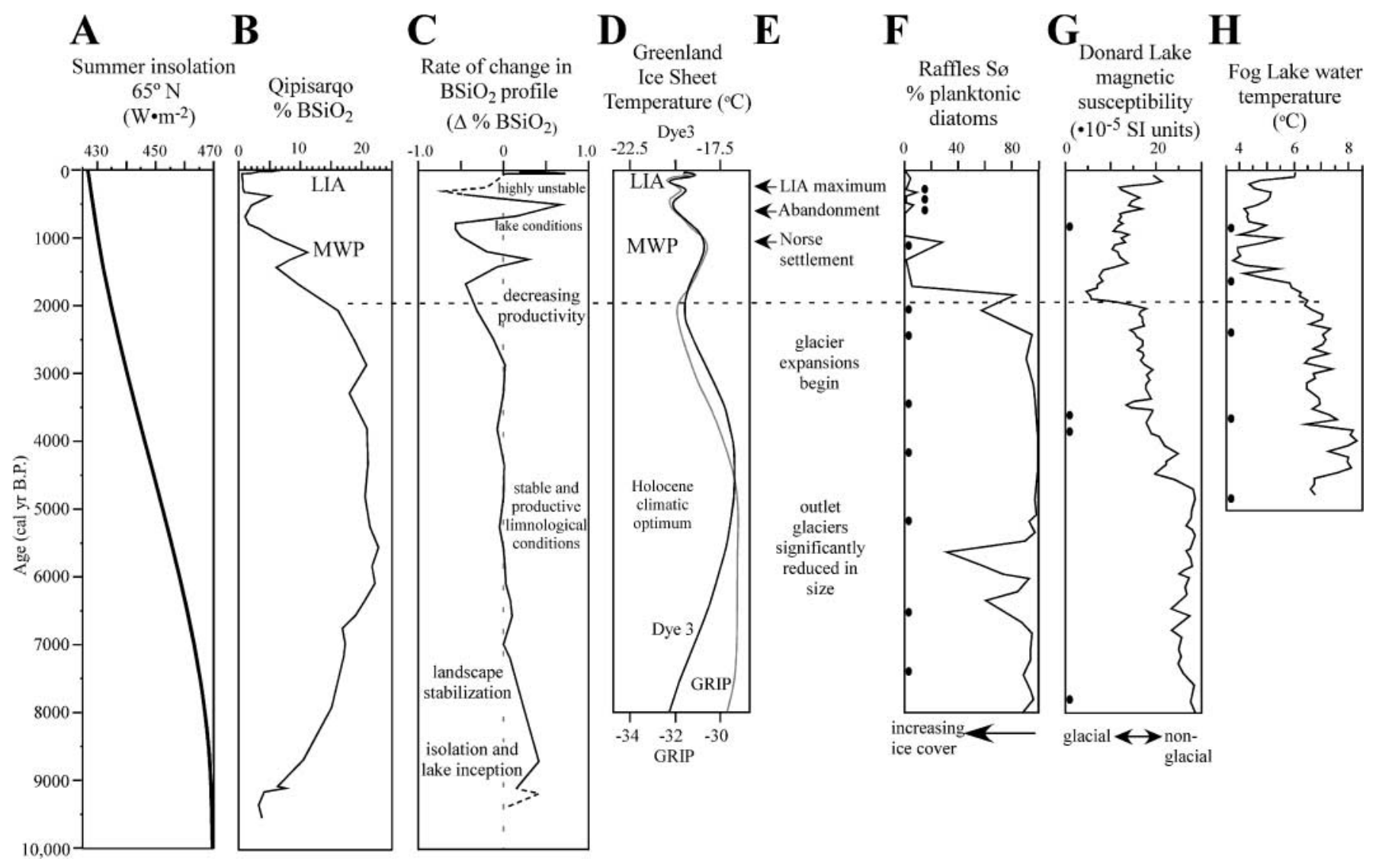

FIG. 5. Northern Hemisphere high-latitude summer insolation (A; Berger, 1978) shown in relation to Qipisarqo Lake BSiO 2 raw data (B) and rates of change (C); borehole paleothermometry from the Greenland Ice Sheet (D; Dahl-Jensen et al., 1998); the glacial geological record of west Greenland (E; Kelly, 1985) and documented Norse chronology for eastern settlement (E; see Ogilvie et al., 2000); the diatom record from Raffles S $\varnothing$, east Greenland (F; Cremer et al., 2001), and two records from Cumberland Peninsula, Baffin Island: magnetic susceptibility from Donard Lake (G; Moore, 1996) and diatom-inferred water temperatures from Fog Lake (H; Joynt and Wolfe, 2001). Black circles in F, G, and H correspond to radiocarbon ages. Horizontal dashed line across the figure highlights the dramatic 3000-2000 cal yr B.P. cooling observed in the Greenland/Baffin Bay region. On the rate of change in $\mathrm{BSiO}_{2}$ curve $(\mathrm{C})$, dashed sections (including glaciolacustrine and glaciomarine sediments) may not be directly comparable to the solid line (gyttja) because they reflect parts of the cores where sediment accumulation rates were dramatically higher (Fig. 2).

along the coast (Dyke et al., 1996), and both glacial (Moore, 1996) and nonglacial (Joynt and Wolfe, 2001; Wolfe, 2002) lakes on Cumberland Peninsula record pronounced cooling. Synchronous cooling is also registered by diatom assemblage changes and decreased sediment $\mathrm{BSiO}_{2}$ on Jameson Land (Cremer et al., 2001), $1800 \mathrm{~km}$ to the northeast of Qipisarqo Lake. This geographic pattern of change (Figs. 1 and 5) implies that the East Greenland, West Greenland, and Baffin currents cooled synchronously in the late Holocene, perhaps in response to an enhanced delivery of Arctic Ocean waters through Denmark Strait and northern Baffin Bay. The corollary to this is that North Atlantic waters delivered via the Irminger Current had diminished influence on the climate of the southern and eastern Greenland coast during this interval.

Neoglacial cooling continued throughout the late Holocene until its culmination during the LIA, although two reversals in the $\mathrm{BSiO}_{2}$ and LOI records, dated 1300-900 cal yr B.P. and 500-280 cal yr B.P., punctuate this overall trend and indicate a climate not simply forced by decreased insolation. The earlier of these events represents the limnological response to the Medieval Warm Period (MWP), associated with a temperature rise over southern Greenland of approximately $1.5^{\circ} \mathrm{C}$ from 2000 to 1100 cal yr B.P. (Dahl-Jensen et al., 1998). The second warming reversal is also coherently recorded in the borehole record (Figs. 5C and 5D), and coincides with brief ameliorated conditions indicated by many European records (e.g., Grove, 1988); at Dye3, Dahl-Jensen et al. (1998) reconstruct a warming of up to $1^{\circ} \mathrm{C}$ between A.D. 1500 and A.D. 1750, prior to pronounced cooling during the second and more severe portion of the LIA. The Qipisarqo Lake lithostratigraphy demonstrates that the last cold interval produced the most extensive Holocene glacial position, as this was the only time the ice sheet's outlet glacier advanced into the lake's catchment and produced a diagnostic sedimentological signature. The evidence indicates that the outlet glacier's advance into the lake's catchment was relatively abrupt (i.e., a short time before the lithologic transition). 
Changes in sediment characteristics do record the initial destabilization of the catchment, leading to increased erosion, well before the glacier advanced into the lake's drainage (Fig. 3). Although volcanic and solar forcing mechanisms appear sufficient to account for LIA cooling (Crowley, 2000), a possible linkage to reduced North Atlantic Deep Water formation has also been suggested, but not confirmed (Keigwin and Boyle, 2000).

The subsequent retreat of Nordre Qipisarqo Bræ from the lake basin is entirely consistent with naturally initiated postLIA warming since A.D. 1850, which is recorded throughout the Arctic (Overpeck et al., 1997). Continued warming led to a return to nonglacial sedimentation in the mid-20th century, by which time anthropogenic greenhouse gases had assumed an important role in climate forcing (e.g., Crowley, 2000). The 45-yr age estimate for initiation of 20th-century gyttja deposition is not necessarily associated with any specific climate event, because glacial retreat leading up to the rerouting of proglacial meltwaters away from the Qipisarqo Lake basin must have been initiated as a response to the 19th-century warming (Overpeck et al., 1997). It is also particularly noteworthy that none of the paleoproduction proxies from Qipisarqo Lake have rebounded to their $6000 \mathrm{cal}$ yr B.P. maximum, implying that current warming, however rapid, has not yet reached peak Holocene warmth.

\section{Rates of Environmental Change and the Context of Norse Settlement}

The overall character of Holocene environmental variability on southern Greenland is well illustrated by the first derivative of the raw Qipisarqo Lake $\mathrm{BSiO}_{2}$ time series (Methods; Fig. 5C), which expresses the rate of change in a proxy that is demonstrably faithful in tracking climate. The rate of change in $\mathrm{BSiO}_{2}$ between the lacustrine gyttja, glaciolacustrine, and glaciomarine sediments may not be directly comparable (Fig. 5) given that sediment accumulation rates are likely to have been dramatically higher in the non-gyttja units (Fig. 2). Nonetheless, this analysis (even if confined to the lacustrine sediments) indicates that the late Holocene (3000-0 cal yr B.P.) is inherently less stable than the previous six millennia and that this instability appears to be ever-increasing, with the highest rates of change confined to the last $1000 \mathrm{yr}$. These observations are contrary to the intuitive notion of greater climatic instability during the early Holocene, which is frequently observed, due to the potential impacts of disintegrating vestigial Wisconsinan ice masses (e.g., Barber et al., 1999). Major climate reversals during the final stages of deglaciation are indeed firmly recorded at the summit of the Greenland Ice Sheet (Alley et al., 1997), and the evidence presented in Figures 3 and 4 suggests southern Greenland remained relatively cold until close to $8000 \mathrm{cal}$ yr B.P. However, it is restated that for at least the last $9000 \mathrm{cal} \mathrm{yr}$ the sensitively positioned Qipisarqo Lake basin records only climate change associated with the LIA as pronounced enough for outlet ice to reach the lake.

When viewed in relationship to the Qipisarqo Lake and other records with sufficient temporal resolution (Fig. 5), it seems probable that climate played an important role in the history of the Norse settlements in Greenland and perhaps Newfoundland (Buckland et al., 1996; Barlow et al., 1997; Ogilvie et al., 2000). Our $\mathrm{BSiO}_{2}$ rate of change curve strongly suggests that Norse movement around the region occurred at perhaps the worst time in the last $10,000 \mathrm{yr}$, in terms of the overall stability of the environment for sustained plant and animal husbandry. The Norse established eastern settlement less than $150 \mathrm{~km}$ from Qipisarqo Lake around A.D. 985 (Fig. 1). The western settlement was also established around this time, $1000 \mathrm{~km}$ north of Qipisarqo Lake, but was then abandoned ca. A.D. 1350, whereas the larger eastern settlement remained until ca. A.D. 1450-1550 (Ogilvie et al., 2000). Colonization around the northwestern North Atlantic occurred during peak MWP conditions that ended in southern Greenland by A.D. 1100. Abandonment of the settlements coincided with subsequent initial LIA cooling which persisted for the next four centuries. The climatic amelioration around A.D. 1500 may have been too late or of insufficient magnitude to reverse the settlements' demise. Our conclusions are consistent with those of Barlow et al. (1997), who carried out a comprehensive study of (the) western settlement that included modeling the detrimental effects of deteriorating climate on farming.

\section{CONCLUSIONS}

Qipisarqo Lake sediment characteristics have been tightly coupled to lake production and Holocene climatic evolution, thereby validating the utility of proxies such as $\mathrm{BSiO}_{2}$ in paleoclimatic applications from Arctic lake sediments. The reconstruction highlights that following a prolonged interval of warm and stable conditions during the middle Holocene, a progression toward increasingly unstable environmental conditions in the late Holocene, likely in part tracking decreased solar insolation. The pronounced interval of Neoglacial cooling between 3000 and 2000 cal yr B.P. appears to be coherently registered in east Greenland as well as both sides of Baffin Bay, suggesting a climate history not just linearly influenced by Milankovitch forcing and a teleconnection involving decreased ocean heat transport in the entire East Greenland-West Greenland-Baffin current system. Following the MWP the LIA contains the most severe climatic conditions regionally of the entire Holocene. Although the congruous timing of Norse history and climate change could be considered circumstantial, at the very least, environmental conditions during this time were highly variable which must have been unfavorable for long-term plant and animal husbandry.

Present and future environmental changes in southern Greenland will likely be superposed on high degrees of already inherent variability. In addition, although lake productivity has not yet reached peak values achieved $6000 \mathrm{cal}$ yr B.P., given the probability of significant future anthropogenic warming (Wigley and Raper, 2001), it seems plausible that the two most extreme Holocene climate states in southern Greenland may occur 
successively within less than 500 yr (cf., Bradley, 2000). The rates and amplitudes of such changes will likely induce ecological changes for which there are no adequate past analogs. Evidence is mounting from lakes in adjacent parts of the Arctic (Douglas et al., 1994; Overpeck et al., 1997; Wolfe and Perren, 2001) that such changes may already be arising.

\section{ACKNOWLEDGMENTS}

Primary support by NSF-ATM 9709918 and, secondary, a Weeks Postdoctoral Fellowship from the Department of Geology and Geophysics, University of Wisconsin-Madison (Kaplan). We thank Jocelyn Turnbull and Scott Lehman for ${ }^{14} \mathrm{C}$ dating, Wendy Freeman for sedimentological analyses, Dierck Kersten and Peter Foister for core sampling assistance, Fred Luiszer for ICP-AES measurements, David Bahr for mathematical assistance, and John Smol and an anonymous reviewer for helping to improve the manuscript. Fieldwork was made possible by Grønlandsfly helicopters and the assistance of Ole Bennike, Jonathan Overpeck, and Alexis Robertson. This is PALE/PARCS contribution number 184 .

\section{REFERENCES}

Abbott, M. B., and Stafford, T. W., Jr. (1996). Radiocarbon geochemistry of modern and ancient arctic lake systems, Baffin Island, Canada. Quaternary Research 45, 300-311.

Alley, R. B., Mayewski, P. A., Sowers, T., Stuiver, M., Taylor, K. C., and Clark, P. U. (1997). Holocene climatic instability: A prominent, widespread event 8200 years ago. Geology 25, 483-486.

Barber, D. C., Dyke, A. S., Hillaire-Marcel, C., Jennings, A. E., Andrews, J. T., Kerwin, M. W., Bilodeau, G., McNeely, R., Southon, J., Morehead, M. D., and Gagnon, J.-M. (1999). Forcing of the cold event of 8,200 years ago by catastrophic drainage of Laurentide lakes. Nature 400, 344-348.

Barlow, L. K., Sadler, J. P., Ogilvie, A. E. J., Buckland, P. C., Amorosi, T., Ingimundarson, J. H., Skidmore, P., Dugmore, A. J., and McGovern, T. H. (1997). Interdisciplinary investigations of the end of the Norse western settlement in Greenland. The Holocene 7, 489-499.

Bennike, O. (2000). Palaeoecological studies of Holocene lake sediments from west Greenland. Palaeogeography, Palaeoclimatology, Palaeoecology 155, 285-304.

Berger, A. (1978). Long term variations of caloric insolation resulting from the Earth's orbital elements. Quaternary Research 9, 139-167.

Blake, W., Jr., Boucherle, M., Fredskild, B., Janssens, J. A., and Smol, J. P. (1992). The geomorphological setting, glacial history and Holocene development of 'Kap Inglefield S $\varnothing$ ', Inglefield Land, North-West Greenland. Meddelelser om Grønland Geoscience 27, 1-42.

Bradley, R. S. (2000). Past global changes and their significance for the future. Quaternary Science Reviews 19, 391-402.

Buckland, P. C., Amorosi, T., Barlow, L. K., Mayewski, P., McGovern, T. H., Ogilvie, A. E. J., and Skidmore, P. (1996). Climate change, bioarchaeology, and the end of Norse settlement. Antiquity 70, 88-96.

Carter, S. J., and Colman, S. M. (1994). Biogenic silica in Lake Baikal sediments: Results from 1990-1992 American cores. Journal of Great Lakes Research 20, 751-760.

Colman, S. M., Peck, J. A., Karabanov, E. B., Carter, S. J., Bradbury, J. P., King, J. W., and Willimans, D. F. (1995). Continental climate response to orbital forcing from biogenic silica records in Lake Baikal. Nature 378, 769-771.

Conley, D. J. (1988). Biogenic silica as an estimate of siliceous microfossil abundance in Great Lakes sediments. Biogeochemistry 6, 161-179.

Cremer, H., Wagner, B., Melles, M., and Hubberten, H. W. (2001). The postglacial environmental development of Raffles S $\varnothing$, east Greenland: Inferences from a 10,000 year diatom record. Journal of Paleolimnology 26, 67-87.
Crowley, T. J. (2000). Causes of climate change over the past 1000 years. Science 289, 270-277.

Dahl-Jensen, D., Mosegaard, K., Gundestrup, G., Clow, G. D., Johnson, S. J., Hansen, A. W., and Balling, B. (1998). Past temperature directly from the Greenland ice sheet. Science 282, 268-271.

Dean, W. E., Jr. (1974). Determination of carbonate and organic matter in calcareous sediments and sedimentary rocks by loss on ignition: Comparison with other methods. Journal of Sedimentary Petrology 44, 242248.

Douglas, M. S. V., Smol, J. P., and Blake, W., Jr. (1994). Marked post-18th century environmental change in high-arctic ecosystems. Science 266, 416419.

Dyke, A. S., Dale, J. E., and McNeely, R. N. (1996). Marine molluscs as indicators of environmental change in glaciated North America and Greenland during the last 18,000 years. Géographie Physique et Quaternaire 50, 125-84.

Edlund, M. B., and Stoermer, E. F. (2000). A 200,000-year high-resolution record of diatom productivity and community makeup from Lake Baikal shows high correspondence to the marine oxygen-isotope record of climate change. Limnology and Oceanography 45, 948-962.

Eggimann, D. W., Manheim, F. T., and Betzer, P. R. (1980). Dissolution and analyses of amorphous silica in marine sediments. Journal of Sedimentary Petrology 50, 215-225.

Engstrom, D. R., and Wright, H. E., Jr. (1984). Chemical stratigraphy of lake sediments as a record of environmental change. In "Lake Sediments and Environmental History" (E. W. Hawworth and J. W. G. Lund, Eds.), pp. 1167. Leicester Univ. Press, Leicester.

Funder, S. (1989). Quaternary Geology of the ice free areas and adjacent shelves of Greenland. In "Quaternary Geology of Canada and Greenland" (R. J. Fulton, Ed.), pp. 741-792. Geological Survey of Canada, Geology of Canada Vol. 1, Ottawa.

Glew, J. R. (1989). A new trigger mechanism for sediment samplers. Journal of Paleolimnology 2, 241-248.

Grove, J. M. (1988). “The Little Ice Age.” Methuen, New York.

Heiri, O., Lotter, A. F., and Lemcke, G. (2001). Loss on ignition as a method for estimating organic and carbonate content in sediments: Reproducibility and compatibility of results. Journal of Paleolimnology 25, 101-110.

Joynt, E. H., III, and Wolfe, A. P. (2001). Paleoenvironmental inference models from diatoms in Baffin Island lakes (Nunavut, Canada), and reconstruction of summer water temperature. Canadian Journal of Fisheries and Aquatic Sciences 58, 1222-1243.

Keigwin, L. D., and Boyle, E. A. (2000). Detecting Holocene changes in thermohaline circulation. Proceedings of the National Academy of Sciences 97, 1343-1346.

Kelly, M. (1985). A review of the Quaternary Geology of western Greenland. In "Quaternary Environments: Eastern Canadian Arctic, Baffin Bay and Western Greenland" (J. T. Andrews, Ed.), pp. 461-501. Allen and Unwin, Boston.

Kerwin, M. W., Overpeck, J. T., Webb, R. S., DeVernal, A., Rind, D. H., and Healy, R. J. (1999). The role of oceanic forcing in mid-Holocene Northern Hemisphere climatic change. Paleoceanography 14, 200-210.

Levesque, A. J., Mayle, F. E., Walker, I. R., and Cwynar, L. C. (1993). A previously unrecognized late-glacial cold event in eastern North America. Nature 361, 623-626.

MacDonald, G. M., Felzer, B., Finney, B. P., and Foreman, S. L. (2000). Holocene lake sediment records of Arctic hydrology. Journal of Paleolimnology 24, $1-14$.

Manabe, S., and Broccoli, A. J. (1985). The influence of the continental ice sheets on the climate of the ice age. Journal of Geophysical Research 90, 2167-2190.

Miller, G. H., Mode, W. N., Wolfe, A. P., Sauer, P. E., Bennike, O., Forman, S. L., Short, S. K., and Stafford, T. W., Jr. (1999). Stratified interglacial lacustrine sediments from Baffin Island, Arctic Canada: Chronology and paleoenvironmental implications. Quaternary Science Reviews 18, 789-810. 
Moore, J. J. (1996). "Glacial and Climatic History of the Cape Dyer Region, Eastern Cumberland Peninsula, Baffin Island, Canada: A Rock Magnetic and Varved Sediment Investigation of Donard Lake.” Unpublished M.Sc. thesis, University of Colorado.

Mortlock, R. A., and Froelich, P. N. (1989). A simple method for the rapid determination of biogenic opal in pelagic marine sediments. Deep Sea Research 36, 1415-1426.

Nesje, A. (1992). A piston corer for lacustrine and marine sediments. Arctic and Alpine Research 24, 257-259.

Noon, P. E., Birks, H. J. B., Jones, V. J., and Ellis-Evans, J. C. (2001). Quantitative models for reconstructing catchment ice extent using physicalchemical characteristics of lake sediments. Journal of Paleolimnology 25, 375-392.

Ogilvie, A. E. J., Barlow, L. K., and Jennings, A. E. (2000). North Atlantic climate c. A.D. 1000: Millennial reflections on the Viking discoveries of Iceland, Greenland and North America. Weather 55, 34-45.

Overpeck, J., Hughen, K., Hardy, D., Bradley, R. S., Case R., Douglas, M., Finney, B., Gajewski, K., Jacoby, G., Jennings, A., Lamoureux, S., Lasca, A., MacDonald, G., Moore, J., Retelle, M., Smith S., Wolfe, A., and Zelinski, G. (1997). Arctic environmental change of the last four centuries. Science $\mathbf{2 7 8}$, 1251-1256.

Putnins, P. (1970). The climate of Greenland. In "Climates of the Polar Regions" (S. Orvig, Ed.), pp. 3-128. World Survey of Climatology, Amsterdam.
Rouse, W. R., Douglas, M. S. V., Hecky, R. E., Hershey, A. E., Kling, G. W., Lesack, L., Marsh, P., McDonald, M., Nicholson, B. J., Roulet, N. T., and Smol, J. P. (1997). Effects of climate change on fresh waters of Region 2: Arctic and Sub-Arctic North America. Hydrologic Processes 11, 873-902.

Schindler, D. W., Beatty, K. G., Fee, E. J., Cruikshank, D. R., Debruyn, E. R., Findlay, D. L., Linsey, G. A., Shearer, J. A., Stainton, M. P., and Turner, M. A. (1990). Effects of climatic warming on lakes of the central Boreal Forest. Science 250, 967-970.

Smith, G. D. (1985). "Numerical Solution of Partial Differential Equations: Finite Difference Methods." Clarendon, Oxford.

Stuiver, M., Reimer, P. J., Bard, E., Beck, J. W., Burr, G. S., Hughen, K. A., Kromer, B., McCormac, F. G., van der Plicht, J., and Spurk, M. (1998). INTCAL98 radiocarbon age calibration $24,000-0$ cal yr B.P. Radiocarbon 40, 1041-1083.

Wigley, T. M. L., and Raper, S. C. B. (2001). Interpretation of high projections for global-mean warming. Science 293, 451-454.

Willemse, N. W., and Törnqvist, T. E. (1999). Holocene century-scale temperature variability from West Greenland lake records. Geology 27, 580-584.

Wolfe, A. P. (2002). Climate modulates the acidity of Arctic lakes on millennial time scales. Geology 30, 215-218.

Wolfe, A. P., and Perren, B. B. (2001). Chrysophycean microfossils record marked responses to recent environmental changes in high- and mid-Arctic lakes. Canadian Journal of Botany 79, 747-752. 